\title{
BISAKAH HAKIM DIJADIKAN SAKSI DI PENGADILAN TATA USAHA NEGARA ?
}

\author{
Oleh \\ Mhd Amin*)
}

\section{Abstrak}

Pengadilan dalam mengadili tidak boleh melakukan diskriminasi baik yang didasarkan pada ras, warna kulit, jenis kelamin, bahasa, agama, pendirian politik, jabatan dalam pemerintahan dan tidak terkecuali solidaritas korps. Pengadilan Tata Usaha Negara sebagai lembaga yang berfungsi untuk mencari kebenaran materil dalam suatu sengketa yang diajukan kepadanya mestinya memfasilitasi apa yang dimohonkan oleh para pihak yang berperkara agar proses pencarian kebenaran materil tersebut benar-benar bisa berjalan sebagaimana mestinya, persoalan apakah yang dimohonkan oleh para pihak yang berperkara tersebut relevan untuk dijadikan sebagai pertimbangan dalam mengambil keputusan, hal itu adalah sepenuhnya kewenangan dari majelis hakim untuk menentukannya, namun apabila permohonan dari pihak yang berperkara itu belum apa-apa sudah ditolak oleh majelis hakim apalagi dasar penolakannya adalah sesuatu yang tidak valid menurut kaidah hukum, seperti penolakan suatu permohonan yang didasarkan atas amanat Undang-undang lalu ditolak berdasarkan isi suatu Surat Edaran Mahkamah Agung adalah sesuatu yang sangat tidak diterima oleh akal sehat mengingat salah satu tugas pokok dan fungsi Pengadilan Tata Usaha Negara itu sendiri adalah untuk menegakkan berlakunya peraturan perundang-undangan sebagaimana mestinya, yang termasuk didalamnya dari sisi penegakan hierarki dari peraturan perundang-undangan.

\section{Kata Kunci : Saksi, Kebenaran Materil}

\section{A.PENDAHULUAN}

Pengadilan sebagai institusi tempat untuk mencari kebenaran dan keadilan mempunyai regulasi yang bisa menjaga keseimbangan agar para pencari keadilan mempunyai kesempatan yang sama untuk memperjuangkan hak-haknya. Dan sebagaimana yang dikemukakan oleh Sjoehran Basah, Peradilan adalah segala sesuatu yang bertalian dengan tugas memutus perkara dengan menerapkan hukum, menemukan hukum in concreto dalam mempertahankan dan menjamin ditaatinya hukum materil dengan meng-

*) Penulis adalah Dosen Fakultas Hukum Universitas Islam Syekh Yusuf gunakan cara prosedural yang ditetapkan oleh hukum formal. ${ }^{1}$

Hukum formal yang sering juga disebut dengan hukum acara berfungsi untuk menjaga keseimbangan hak-hak dari pihak-pihak yang bersengketa di pengadilan terutama dalam upaya mengoptimalkan pencarian rasa keadilan yang diharapkannya, sehingga peradilan yang fair betul-betul terlaksana

${ }^{1}$ Sjoehran Basah, Eksistensi Dan Tolak Ukur Badan Peradilan Administratif Di Indonesia, Alumni Bandung, Cetakan Ketiga, 1997, hlm. 29 
sebagaimana mestinya. Dengan kata lain judicial tyrany tidak akan terjadi.

\section{Metode}

Penelitian ini adalah merupakan penelitian yuridis empiris, yaitu penelitian yang memusatkan perhatian pada kajian tentang norma-norma hukum yang terdapat di dalam peraturan perundangundangan yang dihubungkan dengan fakta-fakta yang terjadi di lapangan/praktek persidangan terutama dalam kasus di Pengadilan Agama Jakarta Barat dalam perkara No. 2313/Pdt.G/2019/ PA.JB. dihubungkan dengan fakta persidangan di Pengadilan Tata Usaha Negara Jakarta dalam perkara No. 24/G/TF/2020/PTUN.JKT.

Adapun sumber data yang dipergunakan adalah sumber data primer, sekunder dan tersier, sementara pendekatan yang dipergunakan adalah pendekatan yuridis empiris.

\section{B. PEMBAHASAN}

Pasal 86 ayat (1) dan (2) Undangundang No. 5 Tahun 1986 tentang Peradilan Tata Usah Negara berbunyi :

(1) Atas permintaan salah satu pihak, atau karena jabatannya, Hakim Ketua Sidang dapat memerintahkan seorang saksi untuk didengar dalam persidangan.

(2) Apabila saksi tidak datang tanpa alasan yang dapat dipertanggung jawabkan meskipun telah dipanggil dengan patut dan Hakim cukup mempunyai alasan untuk menyangka bahwa saksi sengaja tidak datang, Hakim Ketua Sidang dapat memberi perintah supaya saksi dibawa oleh Polisi ke persidangan.

Di bunyi ayat 1 di atas memang ditemukan frasa dapat, yang mengisyaratkan bahwa usulan jadi tidaknya seseorang dipanggil untuk menjadi saksi di persidangan Pengadilan Tata Usaha Negara keputusannya ada di tangan Ketua Majelis Hakim yang memeriksa dan mengadili perkara yang bersangkutan, akan tetapi apabila permohonan yang diajukan oleh para pihak baik itu dari Penggugat atau Tergugat untuk menjadikan seseorang menjadi saksi di persidangan bertumpu kepada kekuatan bunyi pasal dalam Undang-undang, maka apabila Majelis Hakim hendak menolak permohonan tersebut semestinya landasan penolakannya minimal berdasarkan bunyi pasal dari suatu Undang-undang juga, bukan berdasarkan isi suatu ketentuan yang derajatnya dibawah Undang-undang seperti Surat Edaran Mahkamah Agung, sehingga tindakan Majelis Hakim yang berlandaskan Surat Edaran Mahkamah Agung untuk menolak permohonan yang diajukan oleh Penggugat atau Tergugat berlandaskan amanat isi Undang-undang dapat dikualifikasikan sebagai tindakan yang tidak sah menurut hukum, sehingga tindakan Majelis Hakim tersebut tidak menutup kemungkinan dibawa ke Badan Pengawasan Mahkamah Agung atau Komisi Yudisial karena Majelis Hakim telah melaksanakan hukum acara tidak sebagaimana mestinya.

Kemudian bunyi pasal tersebut di atas sangat pas diberlakukan dan ditegaskan di ranah Peradilan Tata Usaha Negara mengingat Pengadilan Tata Usaha Negara adalah sebagai pilar utama negara hukum yang berfungsi untuk mengawal dan mengawasi tegaknya semua peraturan perundang-undangan agar dilaksanakan sebagaimana mestinya sekaligus sebagai pengadilan yang bertujuan untuk mencari kebenaran materil (vide Pasal 107 Undang-undang No. 5 Tahun 1986 tentang Peradilan Tata Usaha Negara). Kemudian bunyi pasal tersebut juga sangat selaras dan sejalan dengan asas hukum yang berbunyi Equality Before The 
Law yang artinya semua orang mempunyai kedudukan yang sama dihadapan hukum. Dan selanjutnya apabila merujuk kepada isi konstitusi kita asas hukum tersebut pengejawantahannya ditemukan di dalam Pasal 27 ayat (1) UndangUndang 1945 yang berbunyi : "Segala Warga Negara bersamaan kedudukannya di dalam Hukum dan Pemerintahan dan wajib menjunjung Hukum dan Pemerintahan itu dengan tidak ada kecualinya", dan juga amanat Pasal 28 $D$ ayat (1) Undang-Undang 1945 yang berbunyi : "Setiap orang berhak atas pengakuan, jaminan, perlindungan, dan kepastian hukum yang adil serta perlakuan yang sama dihadapan hukum".

\section{Hak-Hak Advokat}

Advokat sebagai bagian dari unsur penegak hukum yang posisi dan kedudukannya setara dengan unsur penegak hukum lainnya seperti Polisi, Jaksa dan Hakim sesuai dengan tugas pokok dan fungsinya masing-masing sebagaimana yang diatur oleh peraturan perundangundangan yang berlaku.

Advokat dalam beracara di pengadilan ketika hendak memohonkan sesuatu atau memberikan sanggahan terhadap sikap dan keputusan yang diambil oleh Majelis Hakim harus merujuk kepada ketentuan peraturan perundang-undangan yang berlaku terutama hukum acara. Kemudian disisi lain seorang Advokat dalam menjalankan profesinya mempunyai hakhak yang telah diatur oleh Undangundang terutama dalam melakukan upaya-upaya yang maksimal untuk membela kepentingan hukum kliennya sebagaimana yang diatur dalam Pasal 17 Undang-undang No. 18 Tahun 2003 tentang Advokat telah dijamin kebebasan bagi Advokat untuk mendapatkan informasi, data dan dokumen lainnya untuk pembelaan kepentingan klien, dan untuk lengkapnya bunyi pasal dimaksud dapat dikutip sebagai berikut :

"Dalam menjalankan profesinya, Advokat berhak memperoleh informasi, data, dan dokumen lainnya, baik dari instansi Pemerintah maupun pihak lain yang berkaitan dengan kepentingan tersebut yang diperlukan untuk pembelaan kepentingan Kliennya sesuai dengan peraturan perundang-undangan."

Dan selanjutnya dalam ketentuan yang lebih universal, telah diatur juga prinsip-prinsip dasar tentang peran Advokat/Pembela yang disahkan oleh Kongres Perserikatan Bangsa-Bangsa Kedelapan tentang Pencegahan Kejahatan dan Perlakuan terhadap Pelaku Kejahatan, Havana, Kuba, 27 Agustus sampai 7 September 1990 yang berbunyi :

"Merupakan tugas dari para pejabat yang berwenang untuk memastikan akses para advokat kepada informasi, arsip dan dokumen yang layak yang dimiliki atau dikuasai dalam waktu yang cukup untuk memungkinkan para advokat, memberikan bantuan hukum yang efektif kepada kliennya. Akses tersebut harus diberikan sedini mungkin."2

\section{Kasus}

Pada bulan Juni 2019 ada gugatan mengenai harta pribadi dan harta bersama (gono-gini) di Pengadilan Agama Jakarta Barat yang terdaftar dalam register perkara No. 2313/Pdt.G/2019/ PA.JB. Bahwa dalam proses persidangan perkara tersebut, pihak Penggugat meminta kepada Majelis Hakim agar

2 Adnan Buyung Nasution dk (Penyunting), Instrumen Internasional Pokok Hak Asasi Manusia, Yayasan Obor Indonesia YLBHI Kelompok Kerja Ake Arif, Jakarta, 2006, hlm. 523 
diizinkan untuk melakukan inzage terhadap berkas perkara dalam rangka persiapan menyusun kesimpulan, namun jawaban dari Majelis Hakim tidak memberikan kepastian dan bahkan menyarankan kepada Penggugat agar menulis surat kepada Ketua Pengadilan Agama Jakarta Barat memohon untuk diberikan izin melakukan inzage terhadap berkas perkara No. 2313/Pdt.G/ 2019/PA.JB. Dan atas saran dari Majelis Hakim yang memeriksa dan mengadili perkara No. 2313/Pdt.G/2019/PA.JB. tersebut, Penggugat menulis surat kepada Ketua Pengadilan Agama Jakarta Barat yang isinya mohon agar diizinkan untuk melakukan inzage terhadap berkas perkara No. 2313/Pdt.G/2019/PA.JB. untuk kepentingan pembelaan dalam persiapan menyusun kesimpulan. Atas permohonan tersebut dijawab oleh Ketua Pengadilan Agama Jakarta Barat dengan suratnya No. W9-A2/6654/HK.05/11/2019 tertanggal 28 November 2019 yang isinya pada poin 2 berbunyi sebagai berikut:

2. "Bahwa permohonan inzage terhadap berkas perkara yang sedang diperiksa dengan Nomor 2313/Pdt.G/2019/PAJB tidak dapat dibenarkan, mengingat inzage adalah hak pihak-pihak yang berperkara untuk memeriksa berkas berkaitan dengan pengiriman berkas dalam proses upaya hukum."

Bahwa surat Ketua Pengadilan Agama Jakarta Barat tersebut telah menghilangkan hak-hak Penggugat untuk melakukan inzage, karena tindakan pelarangan inzage yang dilakukan oleh Ketua Pengadilan Agama Jakarta Barat tersebut sangat aneh dan diluar kebiasaan dalam proses pemeriksaan suatu perkara, sebab dalam sistem peradilan yang beradab dan modern dimana sistem peradilan Indonesia termasuk di dalamnya, pengaturan tentang inzage adalah merupakan salah satu cara untuk mengimplementasikan nilai-nilai keterbukaan dalam arti luas antara pencari keadilan dan penegak keadilan serta nilai-nilai kesetaraan dan keseimbangan diantara para pihak yang berperkara. Sebagai pembanding, mekanisme inzage dalam sistem peradilan Tata Usaha Negara di Indonesia dapat ditemukan dalam Pasal 81 Undang-undang No. 5 Tahun 1986 tentang Peradilan Tata Usaha Negara yang berbunyi :

"Dengan izin Ketua Pengadilan, penggugat, tergugat, dan penasihat hukum dapat mempelajari berkas perkara dan surat-surat resmi lainnya yang bersangkutan di kepaniteraan dan membuat kutipan seperlunya."3

Bahwa tindakan Ketua Pengadilan Agama Jakarta Barat yang melarang Penggugat untuk melakukan inzage dapat dikualifikasikan sebagai Perbuatan Melanggar Hukum oleh Badan dan/atau Pejabat Pemerintahan (Onrechtmatige Overheidsdaad). Dan sesuai dengan amanat Pasal 3 Peraturan Mahkamah Agung Republik Indonesia Nomor 2 Tahun 2019 tentang Pedoman Penyelesaian Sengketa Tindakan Pemerintahan dan Kewenangan Mengadili Perbuatan Melanggar Hukum oleh Badan dan/atau Pejabat Pemerintahan (Onrechtmatige Overheidsdaad), menjelaskan bahwa Warga Masyarakat dapat mengajukan Gugatan Tindakan Pemerintahan secara tertulis kepada Pengadilan yang berwenang dengan menyebutkan alasan: a. bertentangan dengan peraturan perundang-undangan; dan $b$. bertentangan dengan asas-asas umum pemerintahan yang baik. ${ }^{4}$

3 C.S.T. Kansil, Kitab Undang-undang Peradilan Tata Usaha Negara, PT. Pradnya Paramita, Jakarta, Cetakan Keempat, hlm. 61

${ }^{4}$ Yuslim, Hukum Acara Peradilan Tata Usaha Negara, Sinar Grafika, Jakarta, Cetakan Ketiga, hlm. 40 
Bahwa tindakan yang dilakukan oleh Ketua Pengadilan Agama Jakarta Barat yang melarang Penggugat untuk melakukan inzage dalam perkara No. 2313/ Pdt.G/2019/PA.JB. adalah perbuatan yang bertentangan dengan peraturan perundang-undangan yaitu Pasal 17 Undang-undang No. 18 Tahun 2003 tentang Advokat dan Yurisprudensi Mahkamah Agung - R.I No. 838 K/SIP/1970 tertanggal 3 Maret $1971^{5}$ serta prinsip-prinsip dasar tentang peran Advokat/Pembela yang disahkan oleh Kongres PBB tanggal 7 September 1990.

Atas tindakan Onrechtmatige Overheidsdaad yang dilakukan oleh Ketua Pengadilan Agama Jakarta Barat tersebut telah didaftarkan gugatan ke Pengadilan Tata Usaha Negara Jakarta yang terdaftar dalam register No. 24/G/TF/2020/PTUN. JKT. Dengan keluarnya nomor register perkara di Pengadilan Tata Usaha Negara Jakarta tersebut berarti proses dismisal dan sidang pendahuluan sudah lolos, dengan kata lain perdebatan apakah tindakan Ketua Pengadilan Agama Jakarta Barat yang melarang Penggugat untuk melakukan inzage tersebut termasuk dalam ranah tindakan yudisial atau administratif sudah selesai, sebab apabila tindakan tersebut termasuk dalam ranah tindakan yudisial berarti tindakan dimaksud tidak bisa diadili di Pengadilan Tata Usaha Negara karena tindakan yudisial hanya bisa diadili dengan cara melakukan upaya hukum banding, tapi apabila tindakan Ketua Pengadilan Agama Jakarta Barat tersebut termasuk dalam ranah tindakan yang bersifat administratif maka tindakan dimaksud bisa diadili di Pengadilan Tata Usaha Negara, dan penilaian tentang apakah hal itu bersifat tindakan yudisial atau administratif keputusannya didapat pada tahap dismisal dan sidang

5 Johanes Usfunan, Perbuatan Pemerintah Yang Dapat Digugat, Djambatan, Jakarta, hlm. 89. pendahuluan di Pengadilan Tata Usaha Negara.

\section{SE-MA Versus Undang-Undang}

Berhubung karena timbulnya gugatan di Pengadilan Tata Usaha Negara Jakarta bermula dari adanya penolakan inzage oleh Majelis Hakim Pengadilan Agama Jakarta Barat yang mengadili perkara No. 2313/Pdt.G/2019/PA.JB. yang kemudian penolakan tersebut dikukuhkan oleh surat Ketua Pengadilan Agama Jakarta Barat No. W9-A2/6654/ HK.05/11/2019 tertanggal 28 November 2019, maka dalam rangka memaksimalkan fungsi Pengadilan Tata Usaha Negara sebagai lembaga peradilan yang berfungsi untuk mencari kebenaran materil (vide Pasal 107 Undang-undang No. 5 Tahun 1986 tentang Peradilan Tata Usaha Negara) menurut logika yang sehat semestinya baik Hakim maupun Panitera Pengganti perkara No. 2313/Pdt.G/2019/PA.JB. harus diajukan sebagai saksi dalam perkara di Pengadilan Tata Usaha Negara (No. 24/G/TF/2020/PTUN.JKT.) untuk mengetahui secara pasti apa sebenarnya yang menyebabkan Majelis Hakim perkara No. 2313/Pdt.G/ 2019/PA.JB. untuk melarang Penggugat melakukan inzage (merujuk kepada isi Pasal 86 ayat (1) dan (2) Undang-undang No. 5 Tahun 1986 tentang Peradilan Tata Usaha Negara), dan permohonan itu sudah diajukan oleh pihak Penggugat, akan tetapi Majelis Hakim Pengadilan Tata Usaha Negara menolaknya berdasarkan SE-MA No. 4 Tahun 2002 tentang Pejabat Pengadilan Yang Melaksanakan Tugas Yustisial Tidak Dapat Diperiksa, Baik Sebagai Saksi Atau Tersangka Kecuali Yang Ditentukan Oleh Undang-Undang.

Rujukan penolakan ini menjadi aneh karena :

1. Perkara ini sudah lolos dalam pemeriksaan dismisal dan pemeriksaan pendahuluan, berarti Pengadilan Tata Usaha Negara Jakarta sudah 
sependapat bahwa materi gugatan yang diajukan kepada Pengadilan Tata Usaha Negara Jakarta ini bukan termasuk dalam ranah yustisial.

2. Bahwa SE-MA Nomor 4 Tahun 2002 tersebut sangat fokus kepada masalah pemidanaan dan menjadikan pejabat pengadilan untuk menjadi saksi dalam kasus pidana sebagaimana dapat dikutip dari alinea pertama SE-MA dimaksud yang berbunyi sebagai berikut :

"Berdasarkan laporan-laporan yang disampaikan kepada Mahkamah Agung RI saat ini Pejabat Pengadilan dalam melaksanakan tugas yustisial seringkali dihadapkan kepada kondisi masyarakat pencari keadilan tidak dapat menerima kenyataan atas pelaksanaan tugas yang dilakukan oleh Pejabat Pengadilan seperti Panitera, Juru Sita, Juru Sita Pengganti dilaporkan kepada pihak Kepolisian telah melakukan perbuatan Pidana."

Sedangkan yang kami mohonkan kepada Majelis Hakim Pengadilan Tata Usaha Negara adalah agar Hakim dan Panitera Pengganti Pengadilan Agama Jakarta Barat yang mengadili perkara No. 2313/Pdt.G/ 2019/PA.JB. dijadikan sebagai saksi dalam perkara di Pengadilan Tata Usaha Negara (vide Pasal 86 ayat (1) dan (2) Undang-undang Nomor 5 Tahun 1986 tentang Peradilan Tata Usaha Negara).

3. Dalam hierarki peraturan perundangundangan yang berlaku di Indonesia, SE-MA derajatnya sangat rendah dibandingkan dengan Undangundang, dengan kata lain isi sebuah SE-MA tidak bisa meniadakan/ mengeliminasi isi Undang-undang (Lex Superior Derogat Legi Inferior : Peraturan yang lebih tinggi menge- sampingkan peraturan yang lebih rendah tingkatannya).

4. Bahwa SE-MA sifatnya mengatur halhal yang bersifat internal, dengan kata lain isi suatu SE-MA tidak bisa membatasi hak-hak warga Negara untuk memohonkan pelaksanaan amanat suatu Undang-undang yang dalam hal ini isi Pasal 86 ayat (1) dan (2) Undang-Undang No. 5 Tahun 1986 tentang Peradilan Tata Usaha Negara.

5. Bahwa kemudian yang dijadikan rujukan dalam SE-MA Nomor 4 Tahun 2002 tersebut adalah SE-MA Nomor 9 Tahun 1976, dimana dalam SE-MA Nomor 9 Tahun 1976 ini juga hanya fokus kepada hal-hal yang menyatakan bahwa Hakim tidak bisa dimintai pertanggungjawaban dalam melaksanakan tugas peradilan berdasarkan Pasal 1365 BW, dengan kata lain Hakim tidak bisa digugat secara perdata atas putusan yang dibuatnya.

Bahwa baik dari ketentuan yang terdapat dalam SE-MA Nomor 4 Tahun 2002 maupun SE-MA Nomor 9 Tahun 1976 tidak ada hal-hal yang bisa dijadikan landasan hukum untuk melarang/ menolak permohonan untuk menghadirkan Hakim dan Panitera Pengganti Pengadilan Agama Jakarta Barat yang memeriksa dan mengadili Perkara No. 2313/Pdt.G/ 2019/PA.JB sebagai saksi di Pengadilan Tata Usaha Negara.

\section{PENUTUP}

Walaupun dari perspektif kajian ilmiah seperti diuraikan di atas sebenarnya tidak ada alasan bagi Majelis Hakim Pengadilan Tata Usaha Negara Jakarta untuk menolak memerintahkan Majelis Hakim dan Panitera Pengadilan Agama Jakarta Barat yang mengadili perkara No. 2313/Pdt.G/2019/PA.JB. untuk dihadirkan sebagai saksi di 
Pengadilan Tata Usaha Negara, namun kenyataannya permohonan untuk dihadirkan sebagai saksi tetap ditolak oleh Majelis Hakim Pengadilan Tata Usaha Negara Jakarta, mungkin inilah yang dilukiskan oleh asas hukum yang berbunyi Nemo Judex Idoneus in Propria (tidak seorangpun yang dapat menjadi hakim yang baik dalam menangani perkaranya sendiri yakni seorang hakim dianggap tidak akan mampu berlaku objektif terhadap perkara bagi dirinya sendiri atau keluarganya/koleganya). Padahal momen ini sangat bagus untuk memperlihatkan kepada masyarakat luas bahwa asas Equality Before The Law benar-benar terlaksana di Indonesia sekaligus memberikan pelajaran kepada Hakim dan Ketua Pengadilan Agama Jakarta Barat dan umumnya kepada seluruh Hakim di Indonesia bahwa dalam menjalankan tugas tidak boleh berbuat semena-mena walaupun ada atribut yang mengatakan bahwa Hakim itu sebagai wakil Tuhan di muka bumi.

Akhirnya goresan tangan ini sekali lagi ingin mengutip asas hukum yang mengatakan Hodi Mihi Cras Tibi : Ketimpangan atau ketidakadilan yang menyentuh perasaan tetap tersimpan dalam hati nurani rakyat.

\section{DAFTAR PUSTAKA}

\section{Buku :}

Basah, Sjoehran, 1997, Eksistensi Dan Tolak Ukur Badan Peradilan Administratif Di Indonesia, Cetakan Ketiga, Alumni Bandung.

Kansil, C.S.T, Kitab Undang-undang Peradilan Tata Usaha Negara, Cetakan Keempat, Jakarta: PT. Pradnya Paramita.
Nasution, Adnan Buyung dk (Penyunting), 2006, Instrumen Internasional Pokok Hak Asasi Manusia, Jakarta: Yayasan Obor Indonesia YLBHI Kelompok Kerja Ake Arif.

Usfunan, Johanes, Perbuatan Pemerintah Yang Dapat Digugat, Jakarta: Djambatan.

Yuslim, Hukum Acara Peradilan Tata Usaha Negara, Cetakan Ketiga, Jakarta: Sinar Grafika.

Peraturan

\section{Republik Indonesia :}

Perundang-Undangan

Undang-Undang Nomor 5 Tahun 1986 tentang Peradilan Tata Usaha Negara.

Undang-Undang Nomor 18 Tahun 2003 tentang Advokat.

Prinsip-prinsip Dasar tentang Advokat/ Pembela yang disahkan oleh Kongres Perserikat BB tanggal 7 September 1990.

Surat Edaran Mahkamah Agung R.I Nomor 4 Tahun 2002 tentang Pejabat Pengadilan Yang Melaksanakan Tugas Yustisial Tidak Dapat Diperiksa, Baik Sebagai Saksi Atau Tersangka Kecuali Yang Ditentukan Oleh Undang-Undang.

Surat Edaran Mahkamah Agung R.I Nomor 9 Tahun 1976 tentang Gugatan Terhadap Pengadilan Dan Hakim.

\section{Putusan :}

Yurisprudensi Mahkamah Agung R.I Nomor $838 \quad \mathrm{~K} / \mathrm{SIP} / 1970$ tertanggal 3 Maret 1971. 
Putusan Pengadilan Agama Jakarta Barat Nomor 2313/Pdt.G/2019/PA.JB. tertanggal 19 Desember 2019.

Putusan Pengadilan Tata Usaha Negara Jakarta Nomor 24/G/TF/2020/PTUN.JKT. tertanggal 2 Juni 2020 